Rightly or wrongly many people believe that a redistribution of the forest resources is needed. It is a fairly common belief that some companies control greater reserves of timber than they can use, while others are short of raw materials. Industry then is faced with a job of public relations. If this growing public opinion is wrong, industry must supply the public with correct information, and if it is true, industry itself should take steps to remedy the situation.

In some provinces there is legislation giving authority to a Minister of the Crown to dispose of timber held under license which otherwise might be lost. Undoubtedly this legislation must have been needed, but many difficulties and dangers will be encountered in the exercise of this authority, and it would seem that action should be taken only in extreme cases.

Much of the waste and loss which has plagued forest industries in the past is being eliminated through chemical research, a field in which industry itself has led the way.

Better utilization in turn will encourage better management of the forests, reduce fre and insect losses and result in more and better timber being produced in a shorter time.

In brief, industry's role in forestry is to open up and utilize our forest wealth, and a healthy, stable forest industry is needed if our forests are to be developed to the full and if they are to be kept healthy and productive.

\title{
DISCUSSION OF PAPERS BY MESSRS. AVERY AND CREIGHTON
}

J. G. Somers, Provincial Forester, Department of Mines and Natural Resources, Winnipeg, Manitoba.

I am almost in full agreement with what Mr. Avery has said, and the only point of omission that I would mention has to do with the importance of public education in forestry. It seems to me that one of the principal functions of government is to educate the general public as to the needs of practicing sound forestry. When so much of our forest land is publicly owned, a well-informed public is of major importance.

I am in agreement with the idea of constructing main access roads to areas of low productivity with a view to salvaging the timber in outlying areas which cannot be developed by industry at a profit, and particularly where the productivity of such an area can be developed to a satisfactory level.

With respect to licences and the honoring of contracts, as mentioned by Mr. Avery, I believe that many of us know of agreements made many years ago and still in good standing, which though quite satisfactory at the time of establishment, fall short in meeting the needs of the present day. Many of these old agreements were made when our forest resources were considered to be inexhaustible, and I believe that it would be in the public interest if such agreements were revised, if possible with the mutual consent of the governments and industries concerned. 
The other day Murray Morison made a remark to the effect that forestry is not something to be handled either by government or industry working alone, but by the two working together and having a common understanding of each other's problems. In my opinion government foresters should recognize that a healthy forest industry is all important to the practice of sound forestry, and that the forest industry in turn should recognize that there is a definite public interest to be served in the management of our forest resource, and that we should work together in solving our problems.

J. W. Giles, Ontario Department of Lands and Forests

In the division of responsibility for forest management as between government and industry, I understand Mr. Avery to suggest that government should be responsible for providing information, conducting research, the planning and building of roads, for supplementing protection and regeneration activities, and for conveying in the lease a reasonable assurance of continuity of tenure. Industry on the other hand will be responsible for the growing, protecting and utilization of the timber crop. In this connection I assume that industry will so modify cutting methods or engage in large-scale planting operations as to ensure keeping the forest area continuously productive. This may involve a considerable expansion in nursery activity across the northern part of the Province.

I believe Mr. Avery's main point had to do with roads, and I would like to say that roads alone will not ensure forest management. It is first necessary to have a plan of development aimed at making all parts of the limit accessible, and the cost of the road construction must be paid for by the timber being cut. If the government builds or finances roads, increased stumpage or toll charges will be made to pay the cost. If industry pays for the roads, the properly appraised stumpage value of the timber with allowances for road costs will bring about the same result. Roads are the first step-the means to the ultimate objective of improved management.

Failure to regenerate an area after cutting or the establishment of a less desirable species or lower volume per acre all reduce the capacity of the area to supply the mill with raw material. I, therefore, emphatically agree that it is the government's responsibility to provide through legislation, regulations and lease for adequate regeneration and the best possible utilization of the forest crop, but legislation alone will not grow trees-only by sincere purpose and diligent effort on the ground can we produce in Canada the highest degree of forest management attainable.

W. C. Harrison, Manitoba Paper Company.

Whereas a few years ago under the system then in force, the industrial forester was employed chiefly as a control man or cut inspection man, today the industrial forester is for the most part an operator. As such, his function, duties and responsibilities are widespread, and he acquires a different concept of his role in, and contribution to, the industry. He is re- 


\section{DISCUSSION}

sponsible to a great extent to the shareholders and directors of his company, and as such he must view the limit holdings as a production unit of the organization in just the same way as the mill is considered a production unit, and he must plan to use that limit to the best possible advantage. He has a responsibility to maintain and develop the productivity of that limit, and therefore, is directly interested in all types of operators who may be working in the area.

.While industry is in business to make money, it is also in business to maintain its limit as a production unit, which involves close co-operation with government on problems of mutual concern and also every effort on the part of foresters to do what they can with the resources and finances available.

\section{B. F. Avery-Central Ontario Section}

Sorry to delay Howard Kennedy's summation, but I would like to correct something he may have inferred from my paper, namely that I thought governments should build roads for industry. I don't have any such idea. The emphasis intended is that government should carry out its own function, at least my concept of government function. It has a responsibility to protect and to administer lands under its jurisdiction. If the federal government is to take for its own purposes such a large portion of the return from forest lands, then by some means some of that money must go back into the woods, not for industry, but to maintain for all of the people the revenue that comes to the people when trees are changed into a saleable product. Roads need to be built out of federal funds through provincial authority to carry out the function that I have tried to describe in my paper. In so far as I know, the forest products industry does not ask anybody to build roads for it within the area which it has received under contract for cutting rights, from some provincial authority.

\section{J. O. Wilson-Quebec section}

I don't know how the licenses are in the Provinces of Ontaraio. In the Province of Quebec our licenses are given to us on condition that we manage them properly, and I maintain this can't be done unless we build a road system. With a proper management plan that involves cutting the wood wherever it is on the limit, a road system is necessary to extract it; one of the fundamental obligations you undertake when you obtain a license is to build your own roads on the limit. There is no question of the state or province supplying the money. It is squarely up to the industry. The failure of industry to build these roads is one of the reasons why limits have been and are being high graded-the only difference is that today we are better organized and doing a better job of high grading. 